\title{
The Aramaic Šap $\bar{p}^{\Upsilon} e l$ in Its Semitic Context
}

\author{
Aaron Michael Butts \\ Department of Semitic and Egyptian Languages and Literatures, \\ The Catholic University of America, Washington, DC, USA \\ buttsa@cua.edu
}

\begin{abstract}
In Aramaic, the productive causative (=c) stem can be reconstructed as *hap il- (suffixconjugation) $\sim{ }^{*} y$ Vhap ${ }^{\text {'il- }}$ (prefix-conjugation) with * $h$ as the causative morpheme. There are, however, also traces in Aramaic of what seems to be a non-productive Cstem in which the causative morpheme is $\check{s}\left(<\right.$ Proto-Semitic $\left.{ }^{*} s^{l}\right)$. This šap $\bar{\varphi}^{\varsigma} e l$, as it is called, was traditionally thought to result from contact with Akkadian, which has a productive C-stem with a causative morpheme $\check{s}\left(<{ }^{*} s^{I}\right)$, i.e., šaprus (stative) $\sim$ ušapris (preterite). Nevertheless, Rabin convincingly argued, against the traditional interpretation, that many šap $\bar{p}^{\varsigma}$ el forms in Aramaic cannot be loanwords from Akkadian. Different suggestions have been made to explain the Aramaic ša $\bar{p}^{\varsigma}$ el forms that are not loanwords from Akkadian. In this article, I propose an additional option: some Aramaic šap $\bar{p}^{\varsigma} \mathrm{el}$ forms are, I argue, backformations from *? ištap ${ }^{\varsigma} a l$ - (suffix-conjugation) *yištap ${ }^{\varsigma} a l-$ (prefix-conjugation), which I reconstruct as the Proto-Aramaic CT-stem inherited from Proto-Semitic.
\end{abstract}

\section{Keywords}

Aramaic - Akkadian - comparative semitics - language contact - analogy - backformation

\section{For Steve Kaufman}


The field of contact linguistics has seen tremendous growth over the last several decades. ${ }^{2}$ An ever-broadening corpus of changes analysed with an increasingly robust methodology has transformed what was once a subfield in historical linguistics into a new field of research in its own right: contact linguistics. ${ }^{3}$ Part of this maturation process has involved critical-and sometimes painfulself-reflection about whether changes long-held to be the result of language contact are in fact so. ${ }^{4}$ Within the study of Semitic languages, an insightful example of this involves contact-induced changes in Aramaic due to Akkadian. ${ }^{5}$ In his Akkadische Fremdwörter als Beweis für babylonischen Kultureinfluss (1915; second ed. 1917), written at the height of pan-Babylonianism in Near Eastern studies, Zimmern proposed a large number of Akkadian loanwords in

1 An earlier version of this article was presented at the conference 'Aramaic — Linguistic Diversity across Three Millennia', at Philipps University Marburg, 25-26 September 2017. I am grateful to the audience for their feedback. I would also like to thank the following people for their comments on this article: Ed Cook, Aaron Rubin, Lucas Van Rompay, as well as the anonymous reviewers. Note the following abbreviations: KAI $=\mathrm{H}$. Donner and W. Röllig, Kanaanäische und aramäische Inschriften mit einem Beitrag von O. Rössler (Wiesbaden: Harrassowitz, 1969-1973); TAD = B. Porten and A. Yardeni, Textbook of Aramaic Documents from Ancient Egypt (Jerusalem: Hebrew University, Dept. of the History of the Jewish People, 1986-1993).

2 There were certainly earlier publications that laid the foundation for this, none more important than U. Weinreich's Languages in Contact. Findings and Problems (New York: Linguistic Circle of New York, 1953). The late 1980s, however, witnessed the publication of several foundational studies, undoubtedly the most important of which was S. Thomason and T. Kaufman, Language Contact, Creolization, and Genetic Linguistics (Berkeley: University of California Press, 1988).

3 The establishment of this field can be illustrated by the creation of new journals, such as Bilingualism: Language and Cognition (since 1998) and The Journal of Language Contact (since 2007/2008), and new book series, such as Studies in Language Contact (Oxford University Press, since 199o); Approaches to Language Contact (Cambridge University Press, since 2011); as well as by the publication of R. Hickey (ed.), The Handbook of Language Contact (Chichester: Wiley-Blackwell, 2010).

4 Consider, for instance, the following quote: 'There are several cautionary tales available in the literature to show that, when history is examined, often features which are 'well known' to have been transferred from one language to another turn out not to have been' (T.J. Curnow, 'What Language Features can be 'Borrowed'?', in A.Y. Aikhenvald and R.M.W. Dixon [eds.], Areal Diffusion and Genetic Inheritance. Problems in Comparative Linguistics [Oxford: Oxford University Press, 2001] pp. 412-436, at p. 422).

5 The same holds true for contact-induced changes in Hebrew due to Akkadian; for which, see P.V. Mankowski, Akkadian Loanwords in Biblical Hebrew (Hss, 47, Winona Lake: Eisenbrauns, 2000). 
Aramaic. ${ }^{6}$ In his Yale dissertation (1970), later published as a monograph (1974), Kaufman re-evaluated the Akkadian influence on Aramaic and showed convincingly that Zimmern had greatly over-reached in his analysis. ${ }^{7}$ Working with a far more solid methodology coupled with developments in both Aramaic studies and Assyriology since Zimmern's time, Kaufman provided a thorough and reliable analysis of contact-induced changes in Aramaic due to Akkadian that has not been supplanted now more than four decades later-and it is also not likely to be so in the near future. ${ }^{8}$ In the present article, written in honour of Kaufman, I revisit once again a feature that has long been considered a contact-induced change in Aramaic, whether due to contact with Akkadian or some other Semitic language(s): the so-called šap ${ }^{\varsigma} e l . I$ argue that some Aramaic šap ${ }^{\Upsilon} e l$ forms are backformations from what I reconstruct as the inherited CTstem in Aramaic. Based on these backformations as well as on any šap $\bar{p}^{\varsigma} \mathrm{el} \mathrm{forms}$ that were transferred from Akkadian, additional šap $\bar{p}^{\varsigma}$ el forms were analogically created in Aramaic.

Setting the Stage: The c-Stem in Aramaic and in Proto-Semitic

The causative stem in Aramaic can be reconstructed without controversy as * hap ${ }^{\varsigma}$ il- (suffix-conjugation) * $y$ Vhap ${ }^{\varsigma} i l-\left(\right.$ prefix-conjugation). ${ }^{9}$ Reflexes of these forms are attested in Syrian Old Aramaic as hmlkny 'he made me king' (KAI 202 A.3) and $y h s k r$ 'he must hand over' (KAI 224.3). Similar forms are also found in Biblical Aramaic, e.g., hanpeq 'he brought out' (Dan. 5:2) and yhahăwe 'he will declare' (Dan. 5:12), though innovative forms are also attested by this time as well. In the prefix conjugation, the intervocalic $h$ was elided giving *yap sil-, e.g., tațlel '(the animal[s]) will find shade' (Dan. 4:9). ${ }^{10}$ The innovative

$6 \quad$ H. Zimmern, Akkadische Fremdwörter als Beweis für babylonischen Kultureinfluss (Leipzig: Hinrichs, 1915; second ed. 1917).

7 S.A. Kaufman, The Akkadian Influences on Aramaic and the Development of the Aramaic Dialects (Ph.D. Thesis, Yale University, 1970); The Akkadian Influences on Aramaic (Assyriological Studies, 19, Chicago: University of Chicago Press, 1974).

8 For the reverse trajectory of Aramaic influence on Akkadian, see now K. Abraham and M. Sokoloff, 'Aramaic Loanwords in Akkadian-A Reassessment of the Proposals', Archiv für Orientforschung 52 (2011), pp. 22-76.

9 See, e.g., H. Gzella, A Cultural History of Aramaic: From the Beginnings to the Advent of Islam (HdO, 111, Leiden: Brill, 2015) pp. 34-35.

10 Note that this innovation might extend back to Old Aramaic if this is the best analysis of the writing yskr (KAI 224.3). So J.A. Fitzmyer, The Aramaic Inscriptions of Sefire (rev. ed.; Rome: Editrice Pontificio Istituto Biblico, 1995) p. 145. Most scholars, however, regard this form as a scribal error for $y h s k r$, which is attested 3 words before. So S. Segert, Altaramäis- 
suffix-conjugation is * ap 'il-, e.g., 'ăqimeh 'he set it up' (Dan. 3:1) with initial ? instead of $h$. This form is either due to the lenition of the historic voiceless glottal fricative $\left({ }^{*} h>^{2}\right)$ or it is a backformation from the prefix-conjugation, which had lost the historic voiceless glottal fricative. The innovative forms * ${ }^{*} p^{\varsigma} i l-\sim$ *yap 'il- became dominant by at least the turn of the Common Era. ${ }^{11}$ This caus-

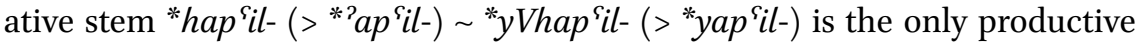
causative stem in Aramaic.

In addition to the productive causative stem discussed in the previous paragraph, Aramaic attests traces of what looks like a causative stem formed with $\check{s}\left(<{ }^{*} s^{I}\right)$ instead of the expected $h\left(>^{7}\right)$. In Syriac, for instance, there is a verbal root $\sqrt{s} h l_{p}$ 'to change (transitive)' attested alongside $\sqrt{h} l p$ 'to change (intransitive)'. Synchronically, these are, I think, best seen as two, independent verbal roots in Syriac. ${ }^{12}$ Diachronically, however, it is not difficult to posit a derivational relationship between the two: $\sqrt{s} s h l p$ 'to change (transitive)' is a causative derived with $\check{s}$ from $\sqrt{h} l p$ 'to change (intransitive)'. A verb such as $\sqrt{ }$ šhlp 'to change (transitive)' is often termed šap $\bar{p}^{\varsigma} \mathrm{el}$ in the secondary literature, and it is this šap ${ }^{\varsigma} \mathrm{el}$ that is the subject of the current paper.

A causative stem beginning with $\check{s}\left(<{ }^{*} s^{I}\right)$ is not surprising within the broad Semitic context. Similar causative stems are attested in a variety of Semitic languages, including Akkadian, Minaic, and Ugaritic. In fact, the Proto-Semitic (= PS) causative stem is to be reconstructed with a causative marker ${ }^{*} s^{1}$ : ${ }^{*}{ }^{1} a C_{1} C_{2} V C_{3^{-}}$(stative/suffix-conjugation) * $y u s^{1} a C_{1} C_{2} i C_{3^{-}}$(preterite/prefixconjugation). The forms with a causative marker of ${ }^{*} h$ (and/or $\left.{ }^{*}\right)$, as are found in Gə⿳亠口冋 ${ }^{\varsigma}$, Mehri, Sabaic, Arabic, Hebrew, and Aramaic, are secondary developments. As is well known, there are a number of places across the Semitic languages where ${ }^{*} s^{1}$ and ${ }^{*} h$ correspond, some of which are outlined in $(1):{ }^{13}$

che Grammatik (Leipzig: Verlag Enzyklopädie, veB, 1975) p. 121; J.C. Greenfield, 'Studies in West Semitic Inscriptions, I: Stylistic Aspects of the Sefire Treaty Inscriptions', Acta Orientalia 29 (1965), pp. 1-18, at p. 9 n. 24; R. Degen, Altaramäische Grammatik der Inschriften des 10.-8.Jh. v. Chr. (Mainz: Deutsche Morgenländische Gesellschaft, 1969) p. 19 n. 79.

11 See M. Sokoloff, 'Outline of Aramaic Diachrony', in C.L. Miller-Naudé and Z. Zevit (eds.), Diachrony in Biblical Hebrew (Linguistic Studies in Ancient West Semitic, 8, Winona Lake: Eisenbrauns, 2012) pp. 379-406, at pp. 392-393.

12 It is for this reason that I insist that Syriac dictionaries (and grammars) treat šh̆lp 'to change (transitive)' as a quadriliteral like any other in the language. For discussion of this question, though I do not agree with all of the conclusions, see W. van Peursen, 'Morpheme or Lexeme: Some Reflections on the Shaphel in Classical Syriac', in J. Dyk and W. van Peursen (eds.), Foundations for Syriac Lexicography, Vol. 3 (Piscataway: Gorgias Press, 2008) pp. 4157 .

13 The only controversial correspondence here is the Aramaic terminative ending $-\supset$ (as well as possibly also Gə`əz $-h a$ ) with Akkadian -iš, Hebrew -ə, and Ugaritic - $h$; for which, 


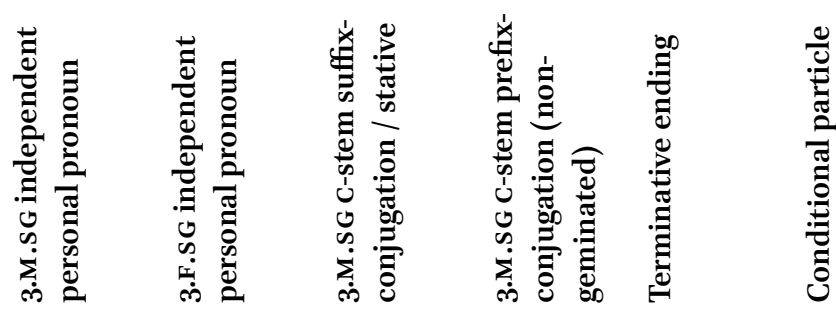

\begin{tabular}{|c|c|c|c|c|c|c|}
\hline Akkadian & $s ̌ \hat{u}$ & $\breve{s} \hat{\imath}$ & šaprus & yušapris & $-i \check{s}$ & šum \\
\hline Gə⿳亠口冋 & wa’atu & $y \partial^{2} \partial t i$ & ${ }^{2} \ddot{a} f^{\varsigma} \ddot{a} l \ddot{a}$ & $y a f^{\varsigma} \partial l$ & $(-h a)$ & 'am \\
\hline Mehri & $h \bar{e}$ & $s e^{-14}$ & harkūb & yəhárkəb & & hām \\
\hline Sabaic & $h^{2}, h w^{2}$ & $h^{?}$ & $h f^{\varsigma} l$ & $y h f^{\varsigma} l$ & & $\mathrm{hm}$ \\
\hline Minaic & $s^{l} w$ & $s^{l} y t$ & $s^{1} f^{\varsigma} l$ & $y s^{1} f^{\varsigma} l$ & & $h m w$ \\
\hline Arabic & huwa & hiya & ${ }^{2} a f^{\varsigma} a l a$ & $y u f^{\varsigma} i l$ & & 'in \\
\hline Ugaritic & $h w$ & hy & $\check{s} p^{\varsigma} l$ & $y s ̌ p^{s} l$ & $-h$ & $h m$, im \\
\hline Hebrew & hu & $h i$ & hip $\bar{p}^{\wedge} i l$ & $\operatorname{yap}^{\varsigma} i l$ & -3 & 'im \\
\hline $\begin{array}{l}\text { Biblical } \\
\text { Aramaic }\end{array}$ & hu & $h i$ & $\begin{array}{c}h a \bar{p}^{\varsigma} e l, \\
\text { etc. }\end{array}$ & $\begin{array}{c}\text { yhap } \bar{p}^{\varsigma} e l, \\
\text { etc. }\end{array}$ & -3 & hen \\
\hline
\end{tabular}

There is a growing consensus that the most economical way to account for the correspondences of ${ }^{*} s^{1} \sim h$ in this table is by positing a sound rule whereby ${ }^{*} s^{1}$ $>h$ in (some of) the West Semitic languages. ${ }^{15}$ While such a rule is now widely accepted, the exact conditioning environment for it remains disputed. One option has been proposed by Huehnergard, who argues that the rule is to be

see A.M. Butts, 'An Aramaic Cognate to Akkadian -iš, Hebrew -0, and Ugaritic - $h$ ', in H.H. Hardy II, J. Lam, and E.D. Reymond (eds.), 'Like 'Ilu Are You Wise': Studies in Northwest Semitic Languages and Literatures in Honor of Dennis G. Pardee (Chicago: Oriental Institute Press, forthcoming).

14 The initial sibilant in this pronoun is not the reflex of PS ${ }^{*} s^{1}$ but, instead, of PS ${ }^{*} s^{3}$; for a recent discussion, see B.D. Suchard, "The Origin of * $s^{3}$ in the Hadramitic and Modern South Arabian Third Person Feminine Personal Pronouns', Jss 62 (2017), pp. 69-76.

15 For brief histories of research, see A. Al-Jallad, 'Yusap'il or Yuhap' ${ }^{\varsigma} \mathrm{il}$, that is the Question. Two Solutions to Sound Change * ${ }^{l}>h$ in West Semitic', zDMG 165 (2015), pp. 27-39, at pp. 27-29; O.D. Gensler, 'Mari Akkadian Iš 'to, for' and Preposition-Hopping in the Light of Comparative Semitic Syntax', Orientalia 66 (1997), pp. 129-156 at p. 135; L. Kogan, 'ProtoSemitic Phonetics and Phonology', in S. Weninger (ed.), The Semitic Languages (Handbücher zur Sprach- und Kommunikationswissenschaft, 36, Berlin: De Gruyter Mouton, 2011) pp. 54-119, at p. 107; R. Voigt 'Die Personalpronomina der 3. Personen im Semitischen', Die Welt des Orients 18 (1987), pp. 49-63, at pp. 50-53. 
restricted to pre-vocalic position. ${ }^{16}$ More recently, Al-Jallad has proposed that the rule operated only at word boundaries. ${ }^{17}$ Both Huehnergard and Al-Jallad must appeal to various analogical developments to explain all the attested forms. ${ }^{18}$ Nevertheless, both proposals do ultimately provide viable explanations. Thus, despite the uncertainty over which conditioning environment is to be preferred (pre-vocalic or at word boundaries), a sound rule of ${ }^{*} s^{1}>h$ remains the best way to account for the correspondences of ${ }^{*} s^{1} \sim h$ in the forms in (1).

If the ${ }^{*} s^{1}>h$ sound rule is accepted, the Aramaic C-stem * hap ${ }^{5} i l-\sim{ }^{*} y$ Vhap 'ilis a straight-forward reflex of the PS C-stems ${ }^{*} s^{l} a C_{1} C_{2} V C_{3^{-}} \sim{ }^{*} y u s^{1} a C_{1} C_{2} i C_{3^{-}}$. The difficulty is how to account for the Aramaic šap ${ }^{\varsigma}$ el forms. These cannot simply be vestiges of the earlier PS C-stem, at least not if we accept some form of the Neo-Grammarian principle of exceptionless sound change. At the same time, however, the Aramaic šap ${ }^{\varsigma} e l$ forms must of course be related to the earlier PS C-stem with ${ }^{*} s^{1}$. How then can we explain the Aramaic šap $\bar{p}^{\varsigma} e l$ historically?

Traditionally scholars considered the šap $\bar{p}^{\Upsilon} e l$ in Aramaic to be the result of contact with Akkadian. ${ }^{19}$ This indeed seems to be the case for at least some lexemes. The Aramaic verbal root $\sqrt{s} y / w z b$ 'to save', for instance, is best explained as a loanword from the Akkadian š-stem ušêzib 'he saved' (preterite) given: 1. that the voiceless pharyngeal stop in the historic root $\sqrt{*} z b$ is not preserved in $\sqrt{s} y / w z b$ as would be expected for a native Aramaic lexeme; and 2. that the voiceless pharyngeal stop would have been lost in Akkadian by the time of the transfer. Thus, Aramaic $\sqrt{s} y / w z b$ is a good candidate for an Akkadian loanword. ${ }^{20}$

16 J. Huehnergard, 'Proto-Semitic and Proto-Akkadian', in G. Deutscher and N.J.C. Kouwenberg (eds.), The Akkadian Language in its Semitic Context. Studies in the Akkadian of the Third and Second Millennium $B C$ (Leiden: Nederlands Instituut voor het Nabije Oosten, 2006) pp. 1-18, at pp. 7-8.

17 Al-Jallad, 'Two Solutions to Sound Change * $s^{1}>h$ in West Semitic'.

18 See the discussion in Butts, 'An Aramaic Cognate to Akkadian - $i \check{s}$, Hebrew -, , and Ugaritic $-h$.

19 See, e.g., H. Bauer and P. Leander, Grammatik des Biblisch-Aramäischen (Halle: Max Niemeyer, 1927) §92k; C. Brockelmann, Grundriss dervergleichenden Grammatik der semitischen Sprachen (Berlin: Reuther \& Reichard, 1908-1913) vol. 1, § 257 f. $\beta$; E.A. Speiser, 'Studies in Semitic Formatives', JAOS 56 (1936) pp. 22-46, at p. 24; Segert, Altaramäische Grammatik, p. 258 .

20 Kaufman considers it to be the only Aramaic šap $\bar{p}^{\varsigma} e l$ that was certainly transferred from Akkadian (Akkadian Influences on Aramaic, pp. 105, 123-124). 
In an important study, however, Rabin definitively showed that most of the šap ${ }^{\Upsilon} e l$ forms in Aramaic are not loanwords from Akkadian. ${ }^{21}$ This is for several different reasons. The most important is that there is often not a potential verb in Akkadian - or at least not one that is attested - from which the Aramaic šap ${ }^{\varsigma}$ el forms could have been transferred. In addition, in some cases even when the root does exist in Akkadian, Akkadian could not have been the source. This is most often the case when the šap $\bar{p}^{\mathrm{el}}$ form in Aramaic preserves one of the five consonants that were lost in Akkadian by the time that it was in contact with Aramaic $\left({ }^{*},{ }^{*} h,{ }^{*} h,{ }^{*}\right.$, and $\left.{ }^{*} \gamma\right)$. So, for instance, Aramaic $\sqrt{s}{ }^{\varsigma} l y$ 'to raise up' cannot be a loanword from Akkadian, even though the cognate šu $l \hat{u}$ is attested there, since the voiceless pharyngeal stop ${ }^{*} \varsigma$ was lost in Akkadian by the time that the transfer would have occurred.

The question then becomes: How do we account for the šap ${ }^{\top} e l$ forms in Aramaic that are not loanwords from Akkadian? Two general answers are found in the scholarly literature, but each of them has its difficulties. ${ }^{22}$ The first answer that I want to discuss also looks to language contact but seeks a source language other than Akkadian. This proposal was first suggested by Rabin in the previously mentioned article. ${ }^{23}$ Rabin proposed that the šap ${ }^{\varsigma} \mathrm{el}$ forms in Aramaic that are not loanwords from Akkadian are the result of contact with another Northwest Semitic language, which he suggested was probably Amorite. Kaufman, however, rejected Amorite as the source of the Aramaic šap $\bar{p}^{\varsigma} e l$ forms, arguing that Amorite does not form the C-stem with ${ }^{*} s{ }^{1}{ }^{14}$ More recently, Streck has argued that Amorite does indeed attest a C-stem with ${ }^{*}{ }^{1}{ }^{125}$ The evidence is not, however, unequivocal.

On the one hand, Streck provides only two possible examples of a C-stem with ${ }^{*} s^{1}$. One is $s a-a k$-la-lu/saklalu/, which he tentatively analyses as 'Perfect(lymade)', comparing the G-stem of the same root in ia-ak-la-al-na-ar /yaklal-nār/ 'Nār-has-proved-to-be-perfect'. ${ }^{26}$ This derivation seems plausible, and I will

21 C. Rabin, 'The Nature and Origin of the Šaf'el in Hebrew and Aramaic', Eretz Israel 9 (1969) pp. $148-158$ (in Hebrew).

22 Kaufman (Akkadian Influences on Aramaic, p. 124 n. 39) provides a succinct and insightful summary of the two options. They are also reviewed in van Peursen, 'Some Reflections on the Shaphel in Classical Syriac', pp. 50-52.

23 Rabin, 'The Nature and Origin of the Šaf'el in Hebrew and Aramaic'.

24 Kaufman, Akkadian Influences on Aramaic, p. 124.

25 M.P. Streck, 'Amorite', in Weninger, The Semitic Languages, pp. 452-459, at p. 466; as well as M.P. Streck, Das amurritische Onomastikon der altbabylonischen Zeit, Vol. 1 (AOAT, 271, Münster: Ugarit-Verlag, 200o) pp. 336-339.

26 For the former name, see J-R. Kupper, Documents administratifs de la salle 135 du Palais de Mari (Archives royales de Mari, XXII/II, Paris: Geuthner, 1983) p. 592; for the latter, see p. 601 in the same volume. 
return to it shortly. The other possible example that Streck cites for a C-stem with ${ }^{*}{ }^{l}$ is $s a-a h$-ba-ru, which he analyses, again tentatively, as sahbaru 'ally'. ${ }^{27}$ This suggestion is less likely in my opinion given the uncertainty over the exact derivation, which Streck does not specify: presumably the root $\sqrt{h} b r$, perhaps in the meaning of the Aramaic G-stem 'to be associated with' and C-stem (but more commonly D-stem) 'to make s.o. an associate'. I am not, however, aware of a C-stem (or even D-stem) nominal derivation of this root in any language, much less one with a meaning 'ally', by which I assume Streck means something like 'one-who-makes-associates'. It should also be noted that the root $\sqrt{h b r}$ is not to my knowledge otherwise attested in Amorite, although this is perhaps less probative given the size of the corpus.

On the other hand, Streck does not, in my view, adequately explain the forms that have traditionally been considered C-stems without $s^{1} .^{28}$ Consider, for instance, ia-ki-in-d IŠKUR 'Hadda-has-made-firm' (3284), which can be compared with the G-stem form of the same root in $i a-k u-u n$-d IšKUR /yakūn-hadda/ 'Hadda-has-proved-to-be-firm' (3335). ${ }^{29}$ Streck argues that the first element in $i a-k i-i n$ - ${ }^{\mathrm{d}}$ ǏKKUR is to be analysed as a D-stem yakin. The form yakin is not, however, expected for the D-stem of II- $w / y$ roots in West Semitic, where the glide is either doubled, as in Syriac qayysm 'he established' $(\sqrt{q w m})$, Arabic șawwara 'he painted', and Ethiopic fäwwäsä 'he healed', or an alternative pattern (so-called Polel) occurs, such as Ugaritic rmm 'he erected' ( $\sqrt{ }$ rwm $)$, Phoenician ytlnn 'he is spending the night (?)' ( $\sqrt{b y n})$, and Hebrew qomem 'he established' $(\sqrt{q w m}){ }^{30}$ Streck cites the Akkadian (Old Babylonian) form $u$ kin (D-

27 For the name, see M. Birot, J.-R. Kupper, and O. Rouault, Répertoire analytique $\left(2^{e}\right.$ volume) (Archives royales de Mari, XVI/I, Paris: Geuthner, 1979) p. 175. Durand tentatively suggests a different derivation of the name as that of an animal (J.-M. Durand, Documents épistolaires du palais de Mari, vol. 2 [Paris: Cerf, 1998] pp. 499-500).

28 As, for instance, in I.J. Gelb, Computer-Aided Analysis of Amorite (Assyriological Studies, 21, Chicago: Oriental Institute of the University of Chicago, 1980).

29 The numbers refer to the listing of personal names found in Gelb, Computer-Aided Analysis of Amorite.

30 For the Hebrew Polel, see E. Kautzsch (trans. A.E. Cowley), Gesenius' Hebrew Grammar (Oxford: Clarendon, 1910) §72m; H. Bauer and P. Leander, Historische Grammatik der hebräischen Sprache des Alten Testamentes (Halle: Niemeyer, 1922) §56k'; P. Joüon and T. Muraoka, A Grammar of Biblical Hebrew (Rome: Editrice Pontificio Instituto Biblico, 1991) §8oh. For the similar forms in Ugaritic, see J. Tropper, Ugaritische Grammatik (AOAT, 273, 2nd ed.; Münster: Ugarit-Verlag, 2012) §74.5; D. Pardee, 'Rezension von J. Tropper, Ugaritische Grammatik (AOAT 273), Ugarit-Verlag, Münster 2000', AfO 50 (2003-2004), pp. 279-285 (online version). And, for Phoenician, see J. Friedrich, with W. Röllig and M.G. Amadasi Guzzo, Phönizisch-Punische Grammatik (Analecta Orientalia, 55, 3rd ed.; Rome: Pontificio Istituto Biblico, 1999) § 166. 
stem preterite of II-w/y root) in support of his analysis, but it is unclear what he means by this: The Amorite form is probably not due to contact with Akkadian given the difference in vocalism in the first syllable, and the Old Babylonian form ukin derives from *yukayyin or the like (compare Assyrian $u k a^{27} i n$ ) due to a contraction of *ayy $i>\bar{i}$, a sound change that probably did not occur in Amorite. ${ }^{31}$ In addition, and more importantly, Streck provides no explanation for the $a$-vowel in the first syllable of yakin if it were to be D-stem. In all of the Semitic languages in which there is evidence for this vowel, it is not * $a$ but * $u$ : Akkadian uparris, Arabic yuqattil, and Gə⿳亠口冋 ${ }^{\varsigma}$ yaqüttal $\left(\partial<{ }^{*} i\right.$, ${ }^{*} u$, but not $\left.{ }^{*} a\right) .{ }^{32}$

Thus, pace Streck, it seems improbable that an Amorite writing such as ia-kiin is to be analysed as a D-stem. It is more likely that such a form is a C-stem, as it has traditionally been understood, even if this necessitates assuming a contraction in the first syllable at a relatively early date (i.e., "yus ${ }^{1}$ akin $>$ * "yuhakin $>$ yakin). Given this evidence, I prefer to follow the traditional understanding in analysing Amorite forms such as yakin as C-stems. Without further arguments, I am unconvinced that the writing sa-ah-ba-ru reflects a C-stem. The form saklalu, however, is more likely to be a C-stem, but it should be noted that a similar C-stem formed with $s^{1}$ from the root $\sqrt{ } k l l$ is also found in Akkadian as well as in Aramaic (already in Biblical Aramaic). Parsimony prompts me, then, to consider Amorite saklalu as an Akkadian loanword (so also probably in Aramaic), and yakin as the inherited c-stem form in Amorite. Thus, my conclusion is much the same as Kaufman's almost 45 years ago: 'While there are a few Amorite names that seem to yield to interpretation best as shaphels, the common causative is certainly haphel: ${ }^{33}$ Ultimately, then, I do not think that Amorite could have been the source of the šap $\bar{\varphi}^{\varsigma}$ el forms in Aramaic.

Nevertheless, even if Amorite does not attest a C-stem with $s^{1}$, some other (Northwest) Semitic language(s) with a š-causative-perhaps unknown languages - could have been the source. This is in fact the explanation preferred by Kaufman as well as by others. ${ }^{34}$ The difficulty with such an appeal to another

31 For this contraction in Babylonian as well as in Old Akkadian, see R. Hasselbach, Sargonic Akkadian (Wiesbaden: Harrassowitz, 2005) pp. 227-228. For the probable lack of this contraction in Amorite, see Streck, Das amurritische Onomastikon der altbabylonischen Zeit, pp. $183-184$.

32 For this * $u$ vowel, see B. Kienast, 'Der Präfixvokal $u$ im Kausativ und im D-Stamm des Semitischen', Münchener Studien zur Sprachwissenschaft 11 (1957), pp. 104-108; F. Rundgren, 'Das Verbalpräfix yu- im Semitischen und die Entstehung der faktitiv-kausativen Bedeutung des D-Stammes', Die Sprache 12 (1966), pp.133-143; B. Kienast, Historische semitische Sprachwissenschaft (Wiesbaden: Harrassowitz, 2001) §187; 197.5C.

33 Kaufman, Akkadian Influences on Aramaic, p. 124 n. 38.

34 Kaufman, Akkadian Influences on Aramaic, p. 124. See also, e.g., S.E. Fassberg, A Grammar 
language is that the source of contact remains undetermined. This is, then, an exemplary case of explaining ignotum per ignotius.

The second way that scholars have attempted to explain the Aramaic šap $\bar{p}^{\varsigma} \mathrm{el}$ forms that are not loanwords from Akkadian is by recourse to analogy. Once loanwords are incorporated into a language they are subject to the same developments, including analogical ones, as any other word in the language. In English, for instance, there are a number of loanwords from Latin in which both the singular and plural were transferred, as in the examples in (2)
(2) a. alumnus $\sim$ alumni
b. fungus $\sim$ fungi

Based on pairs such as these, English-speakers developed a new plural suffix $-i$ for singular nouns ending in -us. This plural suffix $-i$ is found with Latin loanwords such as status and apparatus where the plural is occasionally found as stati and apparati instead of the Latinate plurals statūs and apparatūs (both fifth declension, not second) or the now common English plural statuses and apparatuses. The plural suffix $-i$ also occurs with English nouns that are not of Latin origin, such as the Greek loanword octopus, where the plural octopi is frequently found instead of the Greek plural octopodes. The plurals stati, apparati, and octopi are the result of analogy within English:
(3) alumnus : alumni :: fungus : fungi
:: status $: \mathrm{X}=$ stati
$::$ apparatus $: \mathrm{x}=$ apparati
:: octopus $: \mathrm{X}=$ octopi

Similar developments are attested in the Semitic languages. In Syriac, for instance, the Berufsname suffix -oro developed in a similar way based on pairs

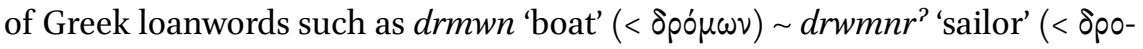
$\mu \omega \nu \alpha \dot{p}(0 \varsigma) .{ }^{35}$ That is, Syriac-speakers formed an agent noun 'ellpors 'sailor' analogically from 'Ellp $\bar{p}$ 'boat' (< Akkadian elippu) based on pairs such as drmwn

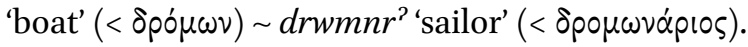

of the Palestinian Targum Fragments from the Cairo Genizah (HSs, 38, Atlanta: Scholars Press, 199o) pp. 85-86; S. Creason, 'Aramaic', in R.D. Woodard (ed.), The Cambridge Encyclopedia of the World's Ancient Languages (Cambridge: Cambridge University Press, 2004) pp. 391-426, at p. 411.

35 See A.M. Butts, Language Change in the Wake of Empire: Syriac in its Greco-Roman Context (Linguistic Studies in Ancient West Semitic, 11, Winona Lake: Eisenbrauns, 2016) pp. 132135 . 
Harris has proposed a similar analogical development for the creation of šap $\bar{p}^{\varsigma} e l$ forms in Aramaic based on šap $\bar{p}^{\varsigma} e l$ forms transferred from Akkadian:

In Aramaic there are a number of verbs in the šafel, borrowed from Akkadian: šêzibl, šaklel, etc. In addition, there are several šafels which must have been formed in Aramaic: e.g. ša $a^{5} b e d$ 'to enslave', which could not have had this phonetic form in Akkadian. These šafels of Aramaic origin could have been patterned upon the borrowed Akkadian causatives: the large group of šafel loan-words had established that form in Aramaic as a recognized causative construction, and then a few Aramaic verbs came to be expressed in the causative on the same pattern. ${ }^{36}$

For Harris, then, some Aramaic šap $\bar{p}^{\varsigma} e l$ forms were created analogically based on Akkadian loanwords in Aramaic such as $\sqrt{s} y / w z b$. The difficulty with this proposal is that there are probably too few Aramaic šap $\bar{p}^{\top} \mathrm{el}$ forms that are loanwords from Akkadian to serve as the basis for such an analogical development. Note Harris's large group of šafel loan-words'. Kaufman, in contrast, considers only one Aramaic šap ${ }^{\Upsilon} e l$ to be a certain Akkadian loanword: $\sqrt{s ̌ y} / w z b$, which was discussed above. ${ }^{37}$ Even if several more were admitted, these would probably not serve as a firm basis from which to have an analogical formation in Aramaic. ${ }^{38}$ It should, however, be pointed out that a number of šap $\bar{p}^{\varsigma} \mathrm{el}$ forms are not attested until Late Aramaic, ${ }^{39}$ and so analogical creation is likely for (some of) these if we are to assume that the lack of earlier attestation is not an accident of preservation. ${ }^{40}$ But, if there are indeed too few Aramaic šap $\bar{p}^{\varsigma} \mathrm{el}$

36 Z.S. Harris, 'Expression of the Causative in Ugaritic', JAOS 58 (1938), pp. 103-111, at p. 110.

37 Kaufman, Akkadian Influences on Aramaic, p. 123 n. 36.

$38 \quad$ For comparison, Syriac contains at least twenty Greek loanwords that end in - $\alpha$ plos as well as, and probably more importantly, at least three pairs of the type $\delta \rho \delta \mu \omega \nu$ 'boat' $\sim \delta \rho \rho \omega \omega \nu \dot{\alpha}-$ plos 'sailor' from which analogy could have easily been made. And, still, non-Greek nouns with the Berufsname suffix -oro in Syriac are much rarer than šap $\bar{\Upsilon}^{\varsigma} e l$ forms in Aramaic are, and interestingly all of these non-Greek nouns with the Berufsname suffix -oro in Syriac are not of ultimate Aramaic origin, suggesting that the words might have been considered 'foreign'. For discussion and examples, see Butts, Language Change in the Wake of Empire, pp. 132-135.

39 For the distribution, see Sokoloff, 'Outline of Aramaic Diachrony', p. 393.

40 Note also that analogy clearly seems to have played a role in the creation of similar-looking verbal forms $\left(\check{s} i \bar{p}^{\varsigma} e l\right)$ in Modern Hebrew; for which, see N. Dekel, 'The šif'el binyan in Israeli Hebrew: Fiction or Reality?' Leeds Working Papers in Linguistics and Phonetics 14 (2009) pp. 1-15, with further references. There are also traces of these verbal forms in Mishnaic Hebrew as well as possible cases in Biblical Hebrew; see J.A. Soggin, 'Tracce di antichi causativi in š- realizzati come radici autonome in ebraico biblico', AION 15 (1965- 
forms that are loanwords from Akkadian to serve as the basis for analogical development, on the basis of which other forms did analogy take place?

To summarise, two options are currently available to explain the šap ${ }^{\varsigma} \mathrm{el}$ forms in Aramaic. In Kaufman's words:

Either all shaphels (and saphels) in Aramaic are the result of outside influence, or among those that had been borrowed (from all sources) there were enough with attested verbal cognates in Aramaic to have allowed the realization that this was indeed a kind of causative conjugation and thus to have served as the model for the formation of a new 'causative' form. ${ }^{41}$

As will have become clear from the discussion above, I do not find either of these options entirely satisfying: I think that some šap $\bar{p}^{\varsigma} e l$ forms are loanwords and that other ša $\bar{p}^{\varsigma} \mathrm{el} \mathrm{forms} \mathrm{are} \mathrm{analogical} \mathrm{creations} \mathrm{(Kaufman's} \mathrm{second} \mathrm{option}$ here), but that it is uncertain whether or not there were enough šap ${ }^{\varsigma} \mathrm{el} \mathrm{forms} \mathrm{in}$ the language to serve as the basis for analogical developments. In the remainder of this paper, I want to propose a third possible explanation for some šap $\bar{p}^{\varsigma} \mathrm{el}$ forms in Aramaic.

\section{A Previously Unconsidered Datum: The CT-Stem in Aramaic}

Before turning to my proposal, I first want to explore what at first glance might seem an unrelated question: What was the form of the cT-stem in ProtoAramaic?

I will first answer in the negative: The cT-stem in Proto-Aramaic was not

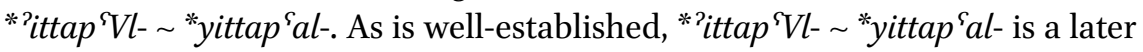
innovation in Aramaic. ${ }^{42}$ This verbal form is not attested in Old Aramaic. There

1966), pp. 17-30 (translated into English in his Old Testament and Oriental Studies [Biblica et Orientalia, 29, Rome: Biblical Institute Press, 1975] pp. 188-202); L. Wächter, 'Reste von Šafel-Bildungen im Hebräischen', ZAW 83 (1971), pp. 380-388.

41 Kaufman, Akkadian Influences on Aramaic, p. 124 n. 139.

42 See, e.g., already M.H. Goshen-Gottstein, 'The System of Verbal Stems in the Classical Semitic Languages', in Proceedings of the International Conference on Semitic Studies held in Jerusalem, 19-23July 1965 (Jerusalem: Israel Academy of Sciences and Humanities, 1969) pp. 70-91, at p. 88 with n. 85; C. Meehan, 'Qal/Pe ${ }^{\varsigma} a l$ as the Passive of Hif ${ }^{\varsigma} i l / A f^{\varsigma} e l$ in Mishnaic Hebrew and Middle Aramaic', in K. Jongeling, H.L. Murre-Van den Berg, and L. Van Rompay (eds.), Studies in Hebrew and Aramaic Syntax: Presented to Professor J. Hoftijzer on 
are a few forms in Achaemenid Aramaic that may well be *ittap ${ }^{\varsigma} V l-\sim$ *yittap $a l$ - The most likely candidates are forms from the root $\sqrt{y s p} \mathrm{C}$ 'to add', such as 'twsp 'it was added' (C3.11:8), since the $w$ would be unlikely - though not impossible - in a GT or DT. ${ }^{43}$ But, even if a form such as 'twsp (C3.11:8) is analysed as *'ittap ${ }^{\varsigma} \mathrm{Vl}-\sim^{*}$ yittap $a l$, this verbal stem was at most marginal in Achaemenid Aramaic. If we move later in time, a clear example of the *ittap ${ }^{\varsigma} \mathrm{Vl}$ $\sim$ *yittap ${ }^{\varsigma} a l$ - is found in the third-century всE Aśoka inscription twice in the verb 'thhsynn 'they stopped' (KAI 279.4, 5). ${ }^{44}$ The etymological writing of $h$ here assures the analysis as * ittap ${ }^{\curlyvee} \mathrm{Vl}$-, but at the same time it may also indicate that the *ittap $V l-\sim{ }^{*}$ yittap ${ }^{\varsigma} a l-$ was a relatively new form: Why else the etymological writing? Could we even be witnessing the incipient stage of the *'ittap ${ }^{\varsigma} \mathrm{Vl}-\sim^{*}$ yittap ${ }^{\varsigma} a l-$ ? By Middle and especially Late Aramaic, the *?ittap ${ }^{\varsigma} \mathrm{Vl}$ $\sim$ *yittap ${ }^{\varsigma} a l$ - becomes more wide-spread even though in a number of dialects it still remains uncommon. ${ }^{45}$ This can be nicely illustrated by the situation in Syriac. The *'ittap ${ }^{\varsigma} V l-\sim{ }^{*}$ yittap ${ }^{\varsigma} a l$ - is significantly limited in the earliest Syriac texts. ${ }^{46}$ For instance, the Syriac version of Eusebius of Caesarea's Ecclesiastical History, which must have been translated by at least the early decades of the fifth century and is attested in a manuscript dated to $461 / 462$ (ms. St. Petersburg, Public Library, Cod. Syr. 1), does not attest the *'ittap ${ }^{\Upsilon} V l-\sim{ }^{*} y i t t a p^{\varsigma} a l-$, suggesting that it was not yet fully established in Syriac at this time. ${ }^{47}$ The Aramaic *ittap ${ }^{\curlyvee} \mathrm{Vl} \sim$ * yittap ${ }^{\varsigma} a l-$, then, is an innovative form that may have started to develop in Achaemenid Aramaic but that was not fully incorporated into

the Occasion of his Sixty-Fifth Birthday (Leiden: Brill, 1991) p. 113;W. Diem, 'Die Entwicklung des Derivationsmorphems der t-Stämme im Semitischen', ZDMG 132 (1982), pp. 29-84, at p. 6o; Kienast, Historische semitische Sprachwissenschaft, §186.5. Gzella (Cultural History of Aramaic, pp. 34-35) is an outlier in reconstructing a CT-stem * ethakteb and *yethaktab to an early stage of Aramaic.

43 Most scholars analyse these forms as *ittap $` V l-;$ see, e.g., K. Beyer, Die aramäischen Texte vom Toten Meer (Göttingen: Vandenhoeck \& Ruprecht, 1984) pp. 150, 469; Kaufman (apud Comprehensive Aramaic Lexicon); T. Muraoka and B. Porten, A Grammar of Egyptian Aramaic (HdO, 32, Leiden: Brill, 2003) § 29. This is not, however, universal; see, e.g., J. Hoftijzer and K. Jongeling, Dictionary of the North-West Semitic Inscriptions (HdO, 21, Leiden: Brill, 1995) vol. 1, p. 824 .

44 See Beyer, Die aramäischen Texte vom Toten Meer, pp. 150, 469.

45 Sokoloff, 'Outline of Aramaic Diachrony', pp. 392-393.

46 So Meehan, ' $\mathrm{Qal} / \mathrm{Pe}{ }^{\varsigma} \mathrm{al}$ as the Passive of $\mathrm{Hif}^{\varsigma}{ }^{`} \mathrm{ll} / \mathrm{Af} f^{\varsigma} \mathrm{el}$ in Mishnaic Hebrew and Middle Aramaic', p. 116.

47 L. Van Rompay, 'Some Preliminary Remarks on the Origins of Classical Syriac as a Standard Language', in G. Goldenberg and Sh. Raz (eds.), Semitic and Cushitic Studies (Wiesbaden: Harrassowitz, 1994) pp. 70-89, at p. 77. I follow Van Rompay in excluding II-w/y roots, which are not related to the matter at hand. 
the verbal system until later, perhaps even much later. ${ }^{48}$ Thus, the Aramaic *'ittap $\mathrm{Vl}-\sim^{*}$ yittap $a l$ - was not the CT-stem in Proto-Aramaic.

What was the CT-stem in Proto-Aramaic, then, if not *'ittap ${ }^{\varsigma} \mathrm{Vl}-\sim^{*}$ yittap ${ }^{\varsigma} a l-?$ I now venture an answer in the positive: The ст-Stem in Proto-Aramaic was, I propose, *i ištap $a l-\sim$ *yištap al-. This is what would be expected in the broader Semitic context. Consider, for instance, the chart in (4), which provides an overview of the C-stems and CT-stems across a range of West Semitic languages along with Akkadian for comparison.

\begin{tabular}{|c|c|c|c|c|}
\hline & $\begin{array}{l}\text { 3.M.SG C- } \\
\text { stem suffix- } \\
\text { conjugation } \\
\text { / stative }\end{array}$ & $\begin{array}{l}\text { 3.M.SG C- } \\
\text { stem prefix- } \\
\text { conjugation } \\
\text { (non-geminated) }\end{array}$ & $\begin{array}{l}\text { 3.M.SG CT- } \\
\text { stem suffix- } \\
\text { conjugation } \\
\text { / stative }\end{array}$ & $\begin{array}{l}\text { 3.M.SG CT- } \\
\text { stem prefix- } \\
\text { conjugation } \\
\text { (non-geminated) }\end{array}$ \\
\hline Akkadian & šaprus & yušapris & šutaprus & uštapris \\
\hline Gə⿳亠丷厂 & ?äf & $y a f^{\varsigma} \partial l$ & ’ästäf $(\ddot{a})^{\varsigma} \ddot{a} l \ddot{a}$ & yastäf ${ }^{\varsigma} a l$ \\
\hline Mehri & harkūb & yahárkab & šənð̄ūr & yəšánðวr \\
\hline Sabaic & $h f^{`} l$ & $y h f^{\prime} l$ & $s t f^{\varsigma} l$ & $\left(y s t f^{\varsigma} l\right)$ \\
\hline Arabic & ${ }^{2} a f^{\varsigma} a l a$ & $y u f^{\varsigma} i l$ & istaf'ala & yastaf'ilu \\
\hline Ugaritic & $s p^{s} l$ & $y \check{s} p^{\varsigma} l$ & $\left(s ̌ t p^{\varsigma} l\right)$ & $y s ̌ t p^{\varsigma} l$ \\
\hline Hebrew & hip $\bar{p}^{\varsigma} i l$ & yap & [hištahăăwo] & [yištah̆ăwe] \\
\hline Aramaic & *hap 'il- & *yVhap sil- & $?$ & $?$ \\
\hline
\end{tabular}

All of the languages that preserve the CT-stem retain the causative marker ${ }^{*}{ }^{l}$. This is obviously to be expected of a language such as Ugaritic, since it also retains the ${ }^{*} s^{l}$ causative marker in the C-stem. But-and this is importanteven in languages in which ${ }^{*} s^{1}$ develops into $h$, such as Gə⿳亠丷厂 $\partial z$, Mehri, Sabaic, and Arabic, the Cт-stem still has a reflex of ${ }^{*} s^{1} .{ }^{49}$ That is, the change of ${ }^{*}{ }^{1}$

48 The Aramaic * ${ }^{2}$ ittap $V l$ should, thus, be added to the list of innovations, such as vowel reduction, the system of nominal states, etc., that are attested across a range of later Aramaic dialects but that are not found in the earliest history of the language. These innovations are outlined in J. Huehnergard, 'What is Aramaic?', ARAM 7 (1994), pp. 261-282, at pp. 266-268. Huehnergard includes *' ittap ${ }^{\Upsilon} V l-\sim$ *yittap ${ }^{\varsigma} a l$ - within his broader discussion of passives formed by a prefixed - $t$ - ('What is Aramaic?', p. 267 [s.v. no. 13]), but he does not deal specifically with the innovation of * ${ }^{*}$ ittap ${ }^{\varsigma} V l-\sim{ }^{*}$ yittap ${ }^{\varsigma} a l-$ itself.

49 The Mehri forms šanðūr yəšánðar (so-called š-stem) are not reflexes of the ProtoSemitic C-stem with ${ }^{*}{ }^{1}$ but instead go back to the Proto-Semitic CT-stem with ${ }^{*}{ }^{1}{ }^{1} t a$ - (see A.D. Rubin, Omani Mehri. A New Grammar with Texts [ssLL, 93, Leiden, Brill: 2018] p. 139). 
to $h$ did not occur in the CT-stem in any language that preserves this stem. This is due to the conditioning factor discussed above, and it can be explained equally well by Huehnergard's proposed prevocalic conditioning factor $\left({ }^{*} s^{1}\right.$ is not prevocalic in the CT-stem and so the rule would not obtain) or by Al-Jallad's proposed word-boundary conditioning factor $\left({ }^{*}{ }^{*} 1\right.$ is not at a word-boundary in the CT-stem and so the rule would not obtain). ${ }^{50}$ I stress: ${ }^{*} s^{1}$ is preserved in the CT-stem in every Semitic language that attests this stem, even if the language has a C-stem in which ${ }^{*} s^{1}>h\left(>^{?}\right)$. And, so, we would expect for ${ }^{*} s^{1}$ to be preserved in the Ст-stem also in Proto-Aramaic, as is reflected in my proposed reconstruction of *ištap ${ }^{\varsigma} a l-\sim$ *yištap ${ }^{\varsigma} a l-$.

A Relic of the Aramaic cT-Stem

Relics of the Proto-Aramaic CT-stem *ištap ${ }^{\varsigma} a l-\sim$ *yištap al- can, I think, be found in what are usually considered to be T-stems of the šap ${ }^{\varsigma} e l$, such as Syriac 'ešta $r b a \underline{d}$ 'he was enslaved' (< *išsta $b a d-$ ), which is synchronically understood as a T-stem of $\sqrt{\check{s}} b d$ 'to enslave. ${ }^{51}$ Note first of all that the T-stem of the šap ${ }^{\Upsilon} e l$ is almost exactly the phonological form that we would expect for the CT-stem in Proto-Aramaic based on the other Semitic languages. The reconstructed suffix-conjugation * 'ištap $a l$ - corresponds exactly as we would expect to Arabic istaf ${ }^{\varsigma} a l a$ and $\mathrm{Gə}^{\top}$ əz ${ }^{\top} \ddot{a s t a ̈ f}(\ddot{a})^{\varsigma} \ddot{a} l \ddot{a} .^{52}$ Similarly, the prefix-conjugation *yištap ${ }^{\varsigma} a l$ - is a very close match to Arabic yastaf ${ }^{\varsigma} i l u$ and Gə⿳亠口冋 ${ }^{\varsigma} \partial \mathrm{z}$ yastäf ${ }^{\varsigma} \partial l$ (< * yāstaf $\left.{ }^{`} i l\right)$ as well as to Akkadian uštapris. The only substantive difference is the vowel between $\mathrm{C}_{2}$ and $\mathrm{C}_{3} .{ }^{53}$ There are various possible explanations for this difference, but I think that the most likely is that in Aramaic the inherited Ст prefix-conjugation *yištap ${ }^{\Upsilon} i l$ - was remodelled on the inherited Ст suffix-

$5^{\circ}$ This of course depends on how exactly one chooses to reconstruct the various protoforms, but this is not at issue here.

51 The kernel of my argument here can already be found in Diem, 'Die Entwicklung des Derivationsmorphems der t-Stämme im Semitischen', pp. 59-6o.

$5^{2}$ The only difference is the realisation of the initial syllable. As the Arabic suggests (with hamzat al-wașl), the initial syllable is probably prothetic to break up an initial consonant cluster (cf. Diem, 'Die Entwicklung des Derivationsmorphems der t-Stämme im Semitischen', p. 45). The Ethiopic form with 'ästä- is a secondary development due to analogy with the C-stem prefix ${ }^{?} \ddot{a}$ - (see G. Goldenberg, 'The Semitic Languages of Ethiopia and their Classification', BSOAS 40 [1977], pp. 461-507, at pp. 498-499; and M. Waltisberg, Die St-Stämme des Altäthiopischen [Munich: Lincom Europa, 2001] § 2.1, both with further references).

53 The vowels in the prefixes are language specific and not of concern here. 
conjugation *ištap $a l$-. This remodelling is to be expected in Aramaic since the bases of the suffix-conjugation and prefix-conjugation are consistently the same in the derived stems in this language. This is illustrated in the following examples from Syriac:

$$
\begin{array}{ll}
\mathrm{GT} & { }^{2} \varepsilon \underline{t} p^{\varsigma} \varepsilon l: n \varepsilon \underline{t} p^{\varsigma} \varepsilon l \\
\mathrm{D} & p a^{\varsigma \varsigma} \varepsilon l: n p a^{\varsigma \varsigma} \varepsilon l \\
\mathrm{DT} & { }^{2} \varepsilon t p a^{\varsigma \varsigma} a l: n \varepsilon t p a^{\varsigma \varsigma} a l \\
\mathrm{C} & { }^{2} a \bar{p}^{\varsigma} \varepsilon l: n a \bar{p}^{\varsigma} \varepsilon l \\
\mathrm{CT} & { }^{2} \varepsilon t t a \bar{p}^{\varsigma} a l: n \varepsilon t t a \bar{p}^{\varsigma} a l
\end{array}
$$

Given the symmetry between the bases of the suffix-conjugation and prefixconjugation throughout the derived stems in Aramaic, it would not be surprising for the inherited prefix-conjugation *yištap ${ }^{\varsigma} i l-$ with ${ }^{*} i$ between $\mathrm{C}_{2}$ and $\mathrm{C}_{3}$ to be remodelled to *yištap ${ }^{\varsigma} a l$ - based on the suffix-conjugation * ${ }^{\text {ištap }}{ }^{\varsigma} a l-.^{54}$ It is possible that this remodelling had not yet occurred in Proto-Aramaic but only later in the language's history, but I have placed it at the proto-language for now since a similar remodelling seems to have also affected the prefix-conjugation of the DT: *yitpa ${ }^{\varsigma \varsigma} a l$ - instead of the expected **yitpa $\varsigma^{\varsigma i l-}$, based on Hebrew yitqattel and Akkadian uptarris, both with ${ }^{*} i$ between $\mathrm{C}_{2}$ and $\mathrm{C}_{3} .{ }^{55}$ Thus, the attested T-stem of the šap $\bar{p}^{\varsigma}$ el is almost an exact morphological match to the expected CT-stem in Proto-Aramaic.

That the T-stem of the Aramaic šap ${ }^{\Upsilon} e l$ is a relic of the CT-stem in ProtoAramaic can be further corroborated by semantics. The semantics of the CTstem in Semitic are notoriously slippery. What is, however, interesting is that the semantics of the T-stem of the Aramaic šap ${ }^{\varsigma} e l$ align remarkably well with what is found with the CT-stem in other languages.

This is perhaps most clear with what is expected as its etymological meaning (at least one of them): a reflexive of the causative. This meaning is found in

54 Other possible explanations for *yištap ${ }^{\varsigma} a l-$ with ${ }^{*} a$ between $\mathrm{C}_{2}$ and $\mathrm{C}_{3}$ include: 1 . The $a$ vowel could have spread from elsewhere in the medio-passive paradigm, including especially the internal passives which must have had an $a$ vowel in this position (see Biblical Aramaic $h u / o \bar{p}^{\varsigma} a l$, along with the remarks in E.M. Cook, 'The Causative Internal Passive in Qumran Aramaic', $A s 8$ [2010], pp. 5-12), as may have also been the case for *ittap ${ }^{\varsigma} a l-<$ *'ittap'il-<*'it-+ * $h /{ }^{\prime} a p^{\varsigma}$ il- (see Cook, 'The Causative Internal Passive in Qumran Aramaic', p. 12). 2. Aramaic * ${ }^{*}$ ištap ${ }^{\varsigma} a$ - could have been remodeled on the DT-stem ( $\left.{ }^{*} y i t p a^{\varsigma \varsigma} a l-\right)$ once the form was lexicalised as the T-stem of a quadriliteral root (for more on this remodeling, see below).

55 Note, however, that Arabic yataqattal and Gə`${ }^{\varsigma}$ zz yətkättäl have * $a$ between $\mathrm{C}_{2}$ and $\mathrm{C}_{3}$ like Aramaic. 
Gə`əz, e.g., Ст 'ästäb ${ }^{\varsigma} \ddot{a} l \ddot{a}$ 'he acquired wealth (sc. made himself wealthy)' compare C 'äb' $\ddot{a} l \ddot{a}$ 'he made wealthy' and Mehri, e.g., šhawūb 'he warmed himself by the fire' compare c $(h)$ hawūb 'he warmed by the fire (transitive)', and it is especially common in Arabic, e.g., С ista ${ }^{\varsigma} a d d a$ 'he made himself ready' compare C ' $a^{\varsigma} a d d a$ 'he made ready'. ${ }^{56}$ Several Aramaic šap ${ }^{\varsigma}$ els have a T-stem with a very similar meaning:

- $\quad \sqrt{s} w h r$ T-stem 'to hesitate, to linger (sc. to delay oneself)', e.g., Syriac

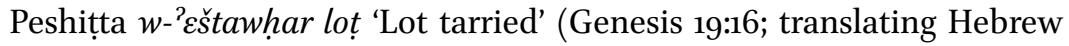
way-yitmahmsh), compare $\sqrt{ }$ ' $h r$ C-stem 'to delay (transitive)'

- $\quad \sqrt{s} h h_{l p}$ T-stem 'to disguise oneself ( $s c$. to change oneself)', e.g., Syriac badmut ${ }^{2} a l(l) i b^{2} \varepsilon t \underline{t} n \underline{\varepsilon} \varepsilon l w^{2} \varepsilon s ̌ t a h l a \bar{p}$ dnat $t^{\varsigma} e$ bnay here 'Like a tempter, he was deceptive and disguised himself, in order to cause the free people to go astray' (Ephrem, Hymns Against Heresies 122.1), ${ }^{57}$ compare $\sqrt{h}$ lp G-stem 'to change (intransitive)'

- $\quad \sqrt{s}$ šț T-stem 'to proceed (sc. to extend oneself)', e.g., nhur bzar`o (emending $b^{\top} a r^{\varsigma}$, following the editor) $k a d$ d ys ${ }^{\varsigma} e$ wmeštawšat 'Let us look at a seed as it sprouts and comes forth' (Kalila and Dimna [later translation]

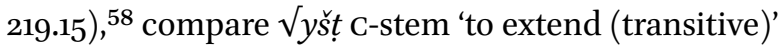

Other examples could be cited, but these should suffice to show that the T-stem of the Aramaic šap $\bar{p}^{\varsigma} \mathrm{el}$ is often a reflexive of the causative, as is found with the

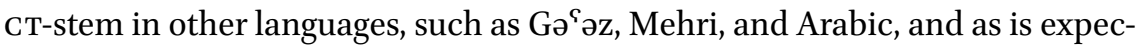
ted etymologically.

Some other semantic categories of the T-stem of the Aramaic šap $\bar{p}^{\varsigma} e l$ are less expected etymologically but are interestingly still found for the CT-stem in other Semitic languages. I want to look at one example involving denominatives. The T-stem of Aramaic $\sqrt{s^{s}} b d$ means 'to be made a slave'. This is curious since the G-stem of $\sqrt{ }^{s} b d$ has the meaning 'to make, act, do' in Aramaic, and it is the noun *s abd- 'slave, servant' that has a meaning related to slavery. Thus, the T-stem of Aramaic $\sqrt{{ }^{\varsigma}} b d$ is a transformative derivation, i.e., the subject changes its state, and it is denominative. ${ }^{59} \mathrm{As}$ it turns out, this semantic derivation is commonly attested with the CT-stem in Arabic (= Form X). Consider,

56 For Gə`` ${ }^{\varsigma}$, see Waltisberg, Die St-Stämme des Altäthiopischen, § 3.9; for Mehri, see Rubin, Omani Mehri, p. 141; for Arabic, see W. Wright, A Grammar of the Arabic Language (3rd ed.; Cambridge: Cambridge University Press, 1896-1898) vol. 2, §61.

Edited in E. Beck, Des heiligen Ephraem des Syrers Hymnen contra Haereses (csco, 169-170, Louvain: Peeters, 1957).

58 Edited in W. Wright, The Book of Kalïlah and Dimnah (Oxford: Clarendon Press, 1884).

59 While I agree with van Peursen that this form must be denominative ('Some Reflections on the Shaphel in Classical Syriac', p. 48 with n. 34), I do not think that his comparison with the Akkadian š-stem is the most apt one, as will become immediately clear. 
for instance, the Arabic Cт forms istawla 'he conquered; he made himself wal $\bar{\imath}$ ' and istahjara 'he became like a stone', both of which are denominative formations (from wali 'master' and hajar- 'stone' respectively). Thus, with the T-Stem of Aramaic $\sqrt{s} s b d$ we have a very close semantic match to what is found with the cT-stem in Arabic. ${ }^{60}$

To summarise, the T-stem of the šap ${ }^{\mathrm{c}} \mathrm{el}$ is very close to the morphological form that we would expect for the CT-stem in Proto-Aramaic based on the other Semitic languages. In addition, the semantics of the T-stem of the šap ${ }^{\varsigma} e l$ align remarkably well with CT forms in other Semitic languages, including in ways that are not necessarily to be expected etymologically. Thus, I propose that at least some T-stems of the šap ${ }^{\varsigma} \mathrm{el}$ are relics of the inherited Proto-Aramaic стstem * ${ }^{*}$ ištap $a l-\sim$ *yištap ${ }^{\varsigma} a l-$.

\section{The Development of the Ša $\bar{p}^{\varsigma} e l$}

I now want to provide a narration of what I think are the historical developments that led to the development of the šap $\bar{p}^{\mathrm{e}}$ in Aramaic. The Proto-Aramaic C-stem was *hap ${ }^{\text {ill }} \sim$ * $y$ Vhap ${ }^{\varsigma}$ il-, and the Proto-Aramaic CT-stem was, I have argued, *? ištap ${ }^{\varsigma} a l-\sim$ * yištap ${ }^{\varsigma} a l-{ }^{61}$ At some point early in the history of Aramaic or even in its prehistory, the inherited cT-stem *ištap ${ }^{\varsigma} a l-\sim^{*}$ yištap ${ }^{\varsigma} a l$ - started to become defunct. This could have been (partly) motivated by the morphological opacity of the form compared to the C-stem. That is, after the sound change of ${ }^{*} s^{1}>h$, the CT-stem, which preserved ${ }^{*} s^{1}$, was no longer clearly identifiable as the reflexive/passive derivation of the C-stem, in which the causative marker was no longer ${ }^{*} s^{1}$. Whatever the motivation(s), however, the loss of the inherited CT-stem in Aramaic should not be surprising given that a similar development occurred in Hebrew: The ст-stem is entirely lost in Hebrew apart from the relic hištahăws yištahăave 'to bow down, prostrate. ${ }^{62}$

6o For the Arabic, see Wright, A Grammar of the Arabic Language, § 65. The CT-stem in Gə``z also derives denominative verbs, but the semantics are active instead of transformative (Waltisberg, Die St-Stämme des Altäthiopischen, § 3.13), e.g., 'ästäwzärä 'he appointed s.o. a vizier', denominative of wäzir 'vizier', which is obviously a loanword from Arabic wazir with the same meaning.

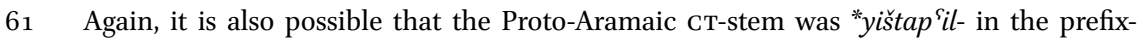
conjugation, more similar to Arabic, Gə` ${ }^{\top} \mathrm{z}$, and Akkadian, and that the development that resulted in ${ }^{*} a$ (instead of ${ }^{*} i$ ) between $\mathrm{C}_{2}$ and $\mathrm{C}_{3}$ happened later in the history of the language.

62 Traditionally, this verb was analysed as deriving from $\sqrt{s} h w$, as, e.g., in F. Brown, S.R. Driver, and C.A. Briggs, A Hebrew and English Lexicon of the Old Testament (Oxford: Clarendon 
While it was in the process of becoming defunct, some inherited СT-stem forms were lexicalised in Aramaic (and in Hebrew). These lexicalised cT-stem forms are what we know synchronically as T-stems of the Aramaic ša $\bar{p}^{\varsigma} \mathrm{el}$. From these lexicalised CT-stems, non-T-stems were derived as backformations, and it is these backformations that we know as the šap $\bar{p}^{\varsigma} \mathrm{el}$ in Aramaic. To make this more concrete by way of an example: I am proposing that the form * ${ }^{*} a^{s} b i d$ - 'he made s.o. a slave' is a backformation from * ${ }^{*} i s t a^{s} b a d$ - 'he was made a slave'. Such a derivation is especially compelling in this particular case since *ša $a^{s} b i d$ - is not an expected causative of the G-stem of $\sqrt{ }{ }^{5} b d$ 'to do', but *išta ${ }^{\varsigma} b a d$ - 'to be made a slave' is an expected CT-stem derivation from a noun * ${ }^{*} a b d$ - 'slave, servant.'63

The development of these backformations could have been partly motivated by the existence of Akkadian loanwords in Aramaic, such as $\sqrt{5} y / w z b$ 'to save'. Even if the number of such Akkadian loanverbs was minimal, as Kaufman for instance thinks, contact with Akkadian still could have been a factor since Aramaic would have been in contact with a related Semitic language, which was culturally more prestigious, that derived causatives with $\check{s}$. The presence of other Semitic languages in the area with š-causatives, such as Ugaritic or even Rabin's and Kaufman's unattested Northwest Semitic language(s), would only have further motivated the backformations. Regardless, however, of what one thinks about the role that Akkadian (or other language[s]) played in this process, at least some Aramaic šap $\bar{p}^{\varsigma} e l$ forms are, I propose, backformations from the inherited CT-stem.

To complete the picture, a new СT-stem was eventually innovated to replace the inherited Ст-stem that had become defunct. This is the ${ }^{*}$ ittap ${ }^{\varsigma} \mathrm{Vl}-\sim$ *yittap'al-. This innovative CT-stem was built by prefixing the reflexive/passive marker * ${ }^{*} i t$ - to the inherited C-stem *hap ${ }^{\wedge} i l-\sim{ }^{*} y$ Vhap ${ }^{\wedge} i l-\left(<\mathrm{PS}^{*}{ }^{1} a C_{1} C_{2} V C_{3^{-}} \sim\right.$

Press, 1907) p. 1005; Kautzsch (trans. Cowley), Gesenius' Hebrew Grammar, §75kk. This changed with the discovery and decipherment of Ugaritic, in which one finds a productive causative with $\check{s}$ as well as cognate forms, such as yšthwy 'he bows down' (Tropper, Ugaritische Grammatik, § 74.6). In light of the Ugaritic evidence, most scholars now analyse Hebrew hištahăws yištahăwe as a relic of a CT-stem with ${ }^{*} s^{1} t a$, from $\sqrt{h w y}$ (see, e.g., Joüon and Muraoka, A Grammar of Biblical Hebrew, §59g). For discussion with references to the earlier literature, see J.A. Emerton, 'The Etymology of hišta ha ${ }^{a} w a \bar{h}$ ', Oudtestamentische Studiën 20 (1977) pp. 41-55 (reprinted in G. Davies and R.P. Gordon, Studies on the Language and Literature of the Bible. Selected Works of J.A. Emerton [Vetus Testamentum Supplements, 165, Leiden: Brill, 2014], ch. 4); and the responses in G.I. Davies, 'A Note on the Etymology of hištah ${ }^{a} w a \bar{h}$ ', Vetus Testamentum 29 (1979), pp. 493-495; and especially S. Kreuzer, 'Zur Bedeutung und Etymologie von hištaḥa wāh / yšthwy', Vetus Testamentum 35 (1985), pp. 39-6o.

63 Again, compare Arabic istawla 'he conquered; he made himself walı' a CT-stem denominative from walı 'master'. 
$\left.{ }^{*} y u s^{1} a C_{1} C_{2} i C_{3^{-}}\right) .{ }^{64}$ This development was in some ways similar to the formation of the šap ${ }^{\varsigma}$ el from the inherited CT-stem ${ }^{*}{ }^{*}$ istap ${ }^{\varsigma} a l-:$ The former involves the analogical creation of a new CT-stem based on the inherited C-stem whereas the latter involves the analogical creation of a new C-stem based on the inherited CT-stem. A primary difference, however, is that the innovative CT-stem * ${ }^{i t t a p}{ }^{\varsigma} \mathrm{Vl}-\sim$ *yittap $a$ al- would eventually become part of the derivational system, whereas šap ${ }^{\Upsilon} e l$ forms existed at best on the fringe of the derivational system and were more likely only ever lexical.

The development of the Aramaic šap ${ }^{\varsigma}$ el that I am proposing here can, I think, be corroborated by the relative frequency of its T- and non-T-stem forms across Aramaic. ${ }^{65}$ Consider the chart in (5), which summarises all the forms of the šap ${ }^{\varsigma}$ el in the Demonstrations attributed to Aphrahat (fl. 336-345). ${ }^{66}$

Non-T-stem T-stem \% T-stem

\begin{tabular}{|c|c|c|c|}
\hline$\sqrt{s ̌ b h r ~ ' t o ~ g l o r i f y ', ~ т ~ ' t o ~ b o a s t ' ~}$ & o & $5^{1}$ & 100 \\
\hline 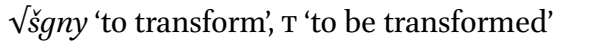 & o & 1 & 100 \\
\hline$\sqrt{s ̌ w} d y \mathrm{~T}$ 'to promise, confess' & o & 12 & 100 \\
\hline$\sqrt{s ̌ w} z b$ 'to save', T 'to be saved' & 15 & 10 & 40 \\
\hline$\sqrt{ }$ šwšt 'to lead', т 'to be extended; to proceed' & o & 2 & 100 \\
\hline$\sqrt{s ̌ w} t p$ 'to unite', $\mathrm{T}$ 'to be united' & 5 & 13 & 72 \\
\hline$\sqrt{s ̌ h} h l p$ 'to change', T 'to be changed' & o & 2 & 100 \\
\hline
\end{tabular}

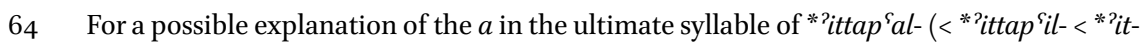
+ " $h /{ }^{\prime} a p^{\varsigma} i(-)$, see Cook, 'The Causative Internal Passive in Qumran Aramaic', p. 12.

65 I would like to thank Steve Kaufman and an anonymous reviewer for encouraging me to pursue this line of inquiry.

66 The Syriac text is edited, with a Latin translation, in I. Parisot, Aphraatis Sapientis Persae Demonstrationes (PS 1.1-2; Paris: Firmin-Didot, 1894-1907). The data derive from a concordance search on the Comprehensive Aramaic Lexicon-more on this important resource shortly. For convenience, I retain Aphrahat as the author of the Demonstrations, although I am generally sympathetic to Walter's recent proposal that the Demonstrations as we now have them represent a collection of pre-existing writings (see J.E. Walters, 'Reconsidering the Compositional Unity of Aphrahat's Demonstrations', in A.M. Butts and R.D. Young [eds.], Syriac Christian Culture: Beginnings to Renaissance [Washington, D.C.: The Catholic University of America Press, forthcoming]). The authorship of these preexisting writings remains, however, an open question for me. 
(cont.)

Non-T-stem T-stem \% T-stem

\begin{tabular}{|c|c|c|c|}
\hline$\sqrt{s ̌ k l l ~ ' t o ~ f i n i s h ', ~ т ~ ' t o ~ b e ~ f i n i s h e d ' ~}$ & 1 & 6 & 86 \\
\hline$\sqrt{s} m l_{y}$ 'to complete', $\mathrm{T}$ 'to be completed' & 0 & 3 & 100 \\
\hline$\sqrt{s} \check{s}^{\varsigma} b d$ 'to enslave', т 'to be enslaved' & 22 & 16 & 42 \\
\hline Total $^{67}$ & 43 & 116 & 73 \\
\hline
\end{tabular}

As is clear from this chart, the T-stem occurs more frequently than the non-Tstem for most šap $\bar{p}^{\varsigma}$ el forms in this text. This distribution departs from that of other roots in Syriac as well as in Aramaic more broadly, in which T-stems occur on average much less frequently than non-T-stems. The relative frequency of $\mathrm{T}$ - and non-T-stem forms of the šap $\bar{p}^{\varsigma} \mathrm{el}$ - with the former being more frequent than the latter-can be explained by the fact that the T-stem of the šap $\bar{p}^{\varsigma} e l$ is inherited whereas the non-T-stem is a secondary innovation.

In the Demonstrations attributed to Aphrahat, there are two outliers in which the non-T-stem of the šap $\bar{p}^{\varsigma} \mathrm{el}$ is more common than the T-stem. One of these is $\sqrt{s} w z b$, which, as discussed above, is a loanword from Akkadian and therefore irrelevant to the discussion at hand since it did not participate in the

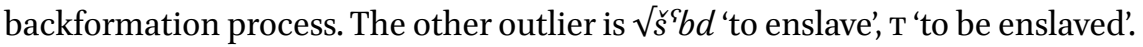
It is important to note that this is among the most common šap ${ }^{\varsigma} e l$ forms in Aramaic. The relatively high frequency of non-T-stem forms of $\sqrt{s} s b d$ is exactly what we should expect for such a common root: With this root, the backformation process is complete, and so $\sqrt{\check{s}} b d$ is simply a quadriliteral root like any other in the language, resulting in the non-T-stem having a higher relative frequency.

The data that I have presented here are of course limited to a single Syriac text, Aphrahat's Demonstrations. I think these data are, however, representative of the relative frequency of T- and non-T-stem forms of the šap ${ }^{\varsigma} e l$ across Aramaic. A broader corpus that includes additional Syriac texts, not to mention texts from other dialects of Aramaic, would undoubtedly further refine my suggestions here. And the Comprehensive Aramaic Lexicon (CAL) - the most important contribution, among many, of Steve Kaufman to the field of Aramaic studies - makes such an analysis possible. For now, however, a more limited

67 If $\sqrt{s} w z b$ 'to save', $\mathrm{T}$ 'to be saved' is removed, since it is a loanword from Akkadian (see the discussion below), then the total percentage of T-stem forms jumps to almost $80 \%(28$ non-T-stem versus $106 \mathrm{~T}$-stem). 
data set must suffice: I propose that the higher frequency of T-stem forms of the šap $\bar{p}^{\varsigma} \mathrm{el}$ compared to non-T-stem forms in Aphrahaț's Demonstrations corroborates my proposal that the šap $\bar{p}^{\varsigma} e l$ is a backformation from the inherited CT-stem.

There is one final point that I would like to make with regard to the relative frequency of $\mathrm{T}$ - and non-T-stem forms of the šap ${ }^{\varsigma} \mathrm{el}$ : In some cases, the only form of a šap ${ }^{\Upsilon} e l$ that is attested is a T-stem. This is, for instance, the case with $\sqrt{s} w d y$ т 'to promise, confess' in the chart above: A non-T-stem is unattested in Syriac and is also not found in Aramaic more broadly. There are a number of other such šap $\bar{p}^{\uparrow}$ el forms in Aramaic that are only attested in the T-stem, including $\sqrt{s} g h r_{\mathrm{T}}$ 'to be cowardly', $\sqrt{s} k p y$ т 'to be overturned', and $\sqrt{s} r k l \mathrm{~T}$ 'to be humiliated'68 The opposite phenomenon, in which only a non-T-stem is attested, is only rarely encountered, and the cases that are not loanwords or denominatives can be explained as due to the accident of survival (i.e., the T-stem is simply unattested in the extant texts). ${ }^{69}$ That there are cases in which only a Tstem of the šap ${ }^{\varsigma} e l$ is attested, such as $\sqrt{s} w d y$ ' 'to promise, confess', combined with the fact that the opposite phenomenon is rare, if not non-existent, again suggests that the šap $\bar{p}^{\varsigma}$ el is a backformation from * ${ }^{i s ̌ t a p}{ }^{\varsigma} a l$-(suffix-conjugation) *yištap ${ }^{\varsigma}$ al-(prefix-conjugation), which I reconstruct as the Proto-Aramaic CTstem inherited from Proto-Semitic.

Parallels for my proposed development of the Aramaic šap $\bar{p}^{\varsigma} e l$ from the inherited СT-stem can be found in at least two Arabic dialects. ${ }^{70}$ One parallel is found in Cairo Arabic. ${ }^{71}$ In this dialect, there are a handful of verbal forms with an initial $s$ - prefix, e.g., sahmid 'to level out' (compare mahhid 'to level'). ${ }^{72}$ According to M. Woidich, these forms are to be analysed as backformations from the ст-

68 I am grateful to Steve Kaufman for providing me a list of these generated from CAL.

69 In contrast, such an explanation is not viable for $\sqrt{s} w d y$, since the T-stem occurs a dozen times in Aphrahaț's Demonstrations and certainly many hundreds of times across the entire Syriac corpus, whereas there is not a single attestation of the non-T-stem.

70 I am grateful to Vera Tsukanova for bringing these parallels to my attention.

71 For an overview of this dialect, see M. Woidich, 'Cairo Arabic', in K. Versteegh (ed.), Encyclopedia of Arabic Language and Linguistics (Leiden: Brill, 2005-2009) vol. 1, pp. 323333 .

72 For these forms, see M. Woidich, Materialen zur Kenntnis des Kairenisch-Arabischen (Amsterdam: Instituut voor het Moderne Nabiije [sic!] Oosten, 199o) p. 96. 
stem (= Form $\mathrm{x}){ }^{73}$ Woidich's proposed development of the Cairo Arabic verb sahmid is, then, similar to what I am proposing for the origins of some Aramaic šap $\bar{p}^{\Upsilon}$ el forms.

An even better parallel for my proposed development involving some Aramaic šap ${ }^{\varsigma}$ el forms is found in Hassāniyya Arabic, which is spoken in the western Sahara, especially in Mauretania, where it is in contact with Berber (particularly Zenaga). ${ }^{74}$ In Hassāniyya Arabic, there is a subset of roots that seem to form a causative-factitive with a prefixed $s a$-, e.g., $s a^{\varsigma} r a b$ 'to arabise' $\left(\sqrt{ }^{\top} r b\right)$ and sahmar 'to make red' $(\sqrt{h} \mathrm{mr}) .{ }^{75}$ In his 1963 grammar of Hassāniyya Arabic, Cohen proposed that these verbs with $s a$ - derive from the historic CT-stem (= Form $\mathrm{x}){ }^{76}$ This analysis was later reaffirmed and further strengthened by Diem and, more recently, by Tsukanova. ${ }^{77}$ Thus, Hassāniyya Arabic verbs such as $s a^{\varsigma} r a b$ 'to arabise' $\left(\sqrt{ }{ }^{\varsigma} r b\right)$ and sahmar 'to make red' ( $\left.\sqrt{h m r}\right)$ seem to be backformations from the CT-stems sta' rab 'to arabise oneself' and stahmar 'to become reddish', respectively. This development is again closely parallel to that proposed here for some Aramaic ša $\bar{p}^{\varsigma} e l$ forms. ${ }^{78}$ What is more, Hassāniyya Arabic is, as already mentioned, in contact with Berber, which has a prefixed marker ssthat forms, inter alia, causatives, e.g., Figuig Berber ssufoy 'to bring out' (compare $f f y$ 'to go out'). ${ }^{79}$ According to Cohen, Diem and Tsukanova, there are good reasons for not considering the causative/factitive $s a$ - prefix in Hassāniyya Arabic to be a loan from Berber, including the different phonological forms of the respective causative markers and that there are no Berber loanverbs in Ḥassāniyya Arabic with this prefix (in contrast to the situation with Aramaic and Akkadian, i.e., $\sqrt{ }$ š $y / w z b$ 'to save'). ${ }^{80}$ The presence of the causative marker $s s$ - in Berber could, however, have helped to motivate the backformation pro-

73 Woidich, Materialen zur Kenntnis des Kairenisch-Arabischen, p. 96.

74 For an overview of this dialect, see C. Taine-Cheikh, 'Hassāniyya Arabic', in Versteegh, Encyclopedia of Arabic Language and Linguistics, vol. 2, pp. 240-250.

75 For the forms, see D. Cohen (with M. el-Chennafi), Le dialecte arabe hassānīya de Mauritanie (parler de la Gabla) (Paris: C. Klincksieck, 1963) pp. 130-133.

76 Cohen (with el-Chennafi), Le dialecte arabe hassānīya de Mauritanie, p. 133.

77 Diem, 'Die Entwicklung des Derivationsmorphems der t-Stämme im Semitischen', pp. 6667 , and V. Tsukanova in a paper presented at the 33. Deutscher Orientalistentag, 1822 September 2017, Friedrich-Schiller-Universität Jena.

78 Diem ('Die Entwicklung des Derivationsmorphems der t-Stämme im Semitischen', pp. 6667) already made the connection between the Ḥassāniyya Arabic forms and the Aramaic šap $\bar{p}^{\mathrm{el}}$ forms.

79 See M. Kossmann, 'Berber Morphology', in A.S. Kaye (ed.), Morphologies of Asia and Africa (Winona Lake: Eisenbrauns, 2007) vol. 1, pp. 429-446, at pp. 440-441.

8o To these reasons, I can add the parallel developments that seem to be attested in Cairo Arabic as well as in Aramaic, if my explanation of some šap $\bar{p}^{\varsigma} \mathrm{el} \mathrm{forms} \mathrm{is} \mathrm{accepted.}$ 
cess, in much the same way as contact with Akkadian may have played a role in the backformation process in Aramaic, as described above. ${ }^{81}$

\section{$9 \quad$ Conclusion}

Scholars have long had recourse to language contact to explain šap $\bar{p}^{\varsigma} e l$ forms in Aramaic. Traditionally, the source of the language contact was thought to be Akkadian. Breaking from the traditional explanation, Rabin convincingly showed that Akkadian could not have been the source; he did not, however, reject an explanation involving language contact but instead appealed to contact with another (Northwest) Semitic language, such as Amorite. Rabin's explanation has proved influential, and many scholars follow it today. In this article, I have proposed an alternative explanation. I have argued that at least some Aramaic šap $\bar{p}^{\varsigma}$ el forms are backformations from *2ištap ${ }^{\varsigma} a l-$ (suffix-conjugation) *yištap ${ }^{\varsigma} a l-($ prefix-conjugation), which I reconstruct as the ProtoAramaic CT-stem inherited from Proto-Semitic. For instance, the form *ša ${ }^{\varsigma} b i d-$ 'he made s.o. a slave' is, I propose, a backformation from * išta $b a d$ - 'he was made a slave'. Such a derivation is especially compelling in this particular case since ${ }^{*} \check{s} a^{\varsigma} b i d$ - is not an expected causative of the G-stem of $\sqrt{\varsigma} b d$ 'to do', but * 'išta 'bad- 'to be made a slave' is an expected CT-stem derivation from the noun * sabd- 'slave, servant'. This proposed development provides an internal Aramaic source for some šap $\bar{p}^{\varsigma}$ el forms in Aramaic. Here I want to stress the word some: I do not think that this development accounts for all of the ša $\bar{p}^{\Upsilon} \mathrm{el}$ forms in Aramaic. ${ }^{82}$ Some are undoubtedly (Akkadian) loanwords, such as $\sqrt{s} y / w z b$ 'to save', and others are probably analogical formations after enough šap $\bar{p}^{\varsigma} \mathrm{el}$ forms were already in Aramaic, whether as loanwords or backformations. Thus, I am sympathetic to one of the options given by Kaufman in the quote above: '... among those [ša $\bar{p}^{\varsigma}$ el forms in Aramaic; АмB] that had been borrowed (from

81 Given the parallels from Aramaic and Hassāniyya Arabic, one wonders if contact with the Egyptian language, especially Coptic, played a role in the creation of forms such as sahmid in Cairo Arabic. The Afroasiastic causative marker * $s$ is not productive in Coptic, but there are relics of it, e.g., smine/semni 'to establish' (< Earlier Egyptian smn 'to make firm') compare moun 'to remain, last' (< Earlier Egyptian $m n$ 'to be firm') and saanš 'to nourish' (< Earlier Egyptian $s^{\text {'nh }}$ 'to make alive, nourish') compare ōnh 'to be alive' (< Earlier Egyptian ' $n h$ h idem) (see A. Loprieno, Ancient Egyptian. A Linguistic Introduction [Cambridge: Cambridge University Press, 1995] p. 250 n. 14). I am grateful to Aaron Rubin for this suggestion.

82 And (probably) also not for so-called sap̄ $\bar{p}^{\mathrm{e}} \mathrm{l}$ forms; for which, see the concluding appendix. 
all sources) there were enough with attested verbal cognates in Aramaic to have allowed the realization that this was indeed a kind of causative conjugation and thus to have served as the model for the formation of a new 'causative' form'. ${ }^{83}$ My aim here is to add backformation from the Proto-Aramaic CT-stem as yet another source for šap $\bar{p}^{\varsigma} \mathrm{el}$ forms in Aramaic, from which further analogical developments could have then occurred. Note that this proposal does not entirely eschew language contact as a factor, but it provides a more nuanced view of the potential contact-induced change: ${ }^{84}$ The backformation process may have been partly motivated by contact with Akkadian, which productively derives causatives with $\check{s}$ - that contact played some role is perhaps even likely in light of the parallel(s) from Modern Arabic. This proposal not only introduces a new explanation for some šap $\bar{p}^{\varsigma} e l$ forms in Aramaic, but it also, I think, has implications for the reconstruction of the ProtoAramaic CT-stem. According to the development proposed here, a form such as *? išta ${ }^{\varsigma} b a d$-, which is synchronically understood as a T-stem of the šap ${ }^{\varsigma} \mathrm{el}$ *ša ${ }^{\varsigma} b i d$-, is actually a relic of the inherited CT-stem in Proto-Aramaic. Thus, I suggest that Aramaic forms such as *? išta ${ }^{\varsigma} b a d$ - corroborate a reconstruction of the CT-stem in Proto-Aramaic as *? ištap`al- (suffix-conjugation) *yištap ${ }^{\varsigma} a l-$ (prefix-conjugation), a reconstruction that is expected based on the broader Semitic evidence.

\section{Appendix: The Aramaic Sap̄ ${ }^{\varsigma} \mathrm{el}$}

Much like the ša $\bar{p}^{\varsigma} e l$, the so-called sa $\bar{p}^{\varsigma} e l$ refers to verbal roots in Aramaic that are synchronically quadriliteral but that diachronically may have a derivational relationship with a triliteral root: For example, $\sqrt{s} r h b$ 'to rush; to impel' and $\mathrm{T}$ 'to be frightened; to move quickly' could potentially have a derivational relationship with $\sqrt{ } \mathrm{rhb} \mathrm{G}$ 'to run' (in Syriac); C 'to frighten'; DT/C ' to be frightened'. Note, however, that the sap $\bar{p}^{\varsigma} e l$ here (and in other potential examples) is not as obviously causative as is the case for many šap $\bar{p}^{\varsigma} \mathrm{el}$ forms. In addition, sap̄el forms, with no more than a half-dozen probable types attested throughout Ara-

83 Kaufman, Akkadian Influences on Aramaic, p. 124 n. 139.

84 One of the ways in which this approach is more nuanced is that it invokes multiple causation: Contact-induced change and internally-motivated change are not binary; in some cases a both-and approach holds more explanatory power (see Butts, Language Change in the Wake of Empire, p. 148, with the literature cited in n. 24). For an example, see the discussion of the development of the copula 'itaw (hy) 'he is' in Syriac against previous proposals (Butts, Language Change in the Wake of Empire, pp. 153-173). 
maic, are not as numerous as the šap $\bar{p}^{\Upsilon} e l$ forms. Finally, it should be noted that most, if not all, of the sap $\bar{p}^{\varsigma} \mathrm{el}$ forms are first attested in Late Aramaic.

The Aramaic sap̄el forms are unique among the Semitic languages in that they seem to reflect a causative-at least arguably so-that is formed with a reflex of Proto-Semitic ${ }^{*} s^{2}$ instead of ${ }^{*} s^{1}$. The most obvious explanation for this would be that at least some, if not most, of the Aramaic sap $\bar{p}^{\mathrm{e}} \mathrm{el}$ forms are loanwords from the Assyrian dialect of Akkadian, since ${ }^{*}{ }^{1}$ (the sibilant of the causative marker) realises as $[\mathrm{s}]$ and not $[\check{s}]$ in this dialect. ${ }^{85}$ Such a derivation would provide a tidy explanation for the prima facie problem with the sibilant of the sap̄ el forms: The reason that Aramaic sap $\bar{p}^{\varsigma} e l$ forms seem to reflect the wrong sibilant is because they are loanwords from Assyrian, in which the sound [s] does in fact go back to the etymologically correct Proto-Semitic sibilant ${ }^{*} s{ }^{1}{ }^{86}$ The difficulty with such an explanation is that none of the Aramaic sap ${ }^{\varsigma}$ el forms are obviously Akkadian loanwords, and some probably cannot be, as is the case with $\sqrt{s r h} b$, since $h$ is preserved. ${ }^{87}$ In addition, as already noted, most, if not all, of the sap̄el forms are first attested in Late Aramaic, and so one would have to assume that they existed in the earlier stage of the language but are as of yet unattested. If any sap $\bar{p}^{\varsigma} \mathrm{el}$ forms are loanwords from Akkadian, then it would be possible for others to be built on analogy. This is especially the case since a very similar set of developments would have been taking place concurrently with the šap ${ }^{\varsigma}$ el forms, with the added difference, of course, that another potential source of šap ${ }^{\varsigma} \mathrm{el} \mathrm{forms} \mathrm{in} \mathrm{Aramaic} \mathrm{is} \mathrm{backformation} \mathrm{from} \mathrm{the}$ Proto-Aramaic CT-stem, as I have proposed here.

Brockelmann has suggested a different explanation for the Aramaic sap ${ }^{\varsigma} \mathrm{el}$ forms: He argues that they are backformations from a CT-stem in Aramaic in which $* \check{s}>s / \_t$ (i.e., $\left.s t>s t\right) .{ }^{88}$ This sound change is, however, ad hoc and not attested elsewhere in Aramaic. ${ }^{89}$ Thus, there is no Aramaic dialect that possess

85 Von Soden's hesitancy in this understanding of the Assyrian reflex of Proto-Semitic ${ }^{*} s^{1}$ is unwarranted (W. von Soden, Grundriss der akkadischen Grammatik [3rd ed.; Analecta orientalia, 33, Rome: Pontificium Institutum Biblicum, 1995] §3od). See more recently Kogan, 'Proto-Semitic Phonetics and Phonology', pp. 88-89 (with abundant literature). Cf. N.J.C. Kouwenberg, A Grammar of Old Assyrian (HdO, 118, Leiden: Brill, 2017) § 3.2.1.3.

86 For this argument involving Assyrian loanwords in Akkadian more broadly, see Kaufman, Akkadian Influences on Aramaic, 141.

$87 \quad$ Note that Kaufman (Akkadian Influences on Aramaic) does not consider any sap̄ $\bar{p}^{\varsigma} \mathrm{el}$ forms to be Akkadian loanwords.

88 Brockelmann, Grundriss der vergleichenden Grammatik der semitischen Sprachen, vol. 1, $\S 257$ f. Anm. 2 (see also $§ 58 \mathrm{~g} \gamma$ ). In light of more recent developments in comparative Semitics, it would be better to reformulate Brockelmann's proposal by stating that ${ }^{*} s^{1}$, when before $t$, realised as $s$ and not $s$.

89 Worse is Bauer and Leander's claim that the Aramaic sap $\bar{p}^{\varsigma} \mathrm{el}$ forms result from a sound 
such CT-stem forms with $s t$, unless we are to analyse ${ }^{*}$ istap ${ }^{\varsigma} a l$ - forms, which are traditionally thought to be T-stem derivations of the sap ${ }^{\mathrm{c}} \mathrm{el}$, as in fact relics of the inherited C T-stem (with št $>$ st), just as I have proposed to do with * ištap ${ }^{\varsigma} a l$ (but without the ad hoc sound change). Given the lack of an Aramaic dialect in which št regularly develops into $s t$ (or better: ${ }^{*} s^{1}>s / \_t$ ), I am hesitant to follow Brockelmann's proposal. If accepted, however, it would provide an explanation for (at least some) sap $\bar{p}^{\varsigma} e l$ forms in Aramaic that is very similar to what I am proposing for some of the ša $\bar{p}^{\varsigma} \mathrm{el} \mathrm{forms.}$

change of $* \check{s}>s$ in certain Aramaic dialects without specifying a conditioning environment (Grammatik des Biblisch-Aramäischen, § 28k). 